\title{
PENINGKATAN DAYA RETENSI SISWA MELALUI LESSON STUDY DENGAN PBL (PROBLEM BASED LEARNING) PADA MATERI LINGKARAN
}

\author{
Naning Kurniawati ${ }^{1}$ \\ Universitas Nahdlatul Ulama Sunan Giri, naningkurniawati@ unugiri.ac.id ${ }^{1}$ \\ Received : 10 Maret 2018, Accepted : 1 April 2018, () Mathematics Education Unugiri 2018
}

\begin{abstract}
Lesson study (LS) is a continuous assessment activity conducted by a group of teachers / lecturers on a regular and continuous basis to test and improve the effectiveness of learning. Lesson study through planning activities, implementation (do) and reflection (see) collaboratively which aims to improve the quality of learning. Lesson Study conducted can encourage students to learn actively, creatively, precisely and fun. Lesson Study can also improve the observation capabilities in the classroom so that teachers can pay attention to the students one by one. Lesson study activities conducted at SMPN 1 Baureno aims to improve teacher competence and improve the quality of learning in the classroom. At the time of open class, learning is done by approach of PBL (Problem Based Learning) which is equipped with worksheet. The PBL (Problem Based Learning) approach or problem based learning is chosen because it can improve students retention by finding principles and formulas. According to the observer, open class activities with group discussion methods can improve students' understanding and retention of the material so that students remember longer material and can apply the formula appropriately. With Lesson Study more enjoyable learning so that students are more enthusiastic in following learning.
\end{abstract}

Keywords: Lesson Study, PBL (Problem Based Learning), retention

\begin{abstract}
Abstrak
Lesson study (LS) yaitu kegiatan pengkajian berkelanjutan yang dilakukan sekelompok guru/dosen secara berkala dan berkelanjutan untuk menguji dan meningkatkan keefektifan pembelajaran. Lesson study melalui kegiatan perencanaan (plan), pelaksanaan (do) dan refleksi (see) secara kolaboratif yang bertujuan untuk memperbaiki kualitas pembelajaran. Lesson Study yang dilakukan dapat mendorong siswa belajar dengan aktif, kreatif, tepat dan menyenangkan. Lesson Study juga dapat meningkatkan kemampuan observasi di kelas sehingga guru dapat memperhatikan siswa satu persatu. Kegiatan lesson study yang dilaksanakan di SMPN 1 Baureno bertujuan untuk meningkatkan kompetensi guru dan meningkatkan mutu pembelajaran di kelas. Pada saat open class, pembelajaran dilaksanakan dengan pendekatan PBL (Problem Based Learning) atau pembelajaran berbasis masalah yang dilengkapi dengan lembar kerja. Pendekatan PBL (Problem Based Learning) atau pembelajaran berbasis masalah dipilih karena dapat meningkatkan daya retensi siswa dengan menemukan prinsip dan rumus. Menurut observer, kegiatan open class dengan metode diskusi kelompok dapat meningkatkan pemahaman dan daya retensi siswa terhadap materi sehingga siswa lebih lama mengingat materi dan dapat mengaplikasikan rumus dengan tepat. Dengan Lesson Study pembelajaran lebih menyenangkan sehingga siswa lebih antusias dalam mengikuti pembelajaran.
\end{abstract}

Kata kunci: Lesson Study, PBL (Problem Based Learning), daya retensi

\section{Pendahuluan}

Matematika merupakan salah satu pelajaran yang menjadi sumber belajar bagi pelajaran yang lain. Jika siswa mudah memahami pelajaran matematika maka siswa juga akan mudah memahami pelajaran yang lain, khusunya di pelajaran ilmu pengetahuan alam. Matematika merupakan pelajaran yang 
banyak melibatkan pemikiran secara medalam, baik pemikiran secara logika, aplikasi atau penggunaan rumus maupun ketepatan dalam berhitung.

Salah satu unsur dalam pembelajaran matematika banyak melibatkan aplikasi atau penggunaan rumus. Biasanya pembelajaran yang diterapkan adalah dengan memberikan rumus, contoh soal kemudian siswa diminta untuk menggunakan rumus tersebut. Dari pengalaman terdahulu cara memberikan rumus secara langsung membuat siswa mudah lupa karena daya retensi rendah.

Beberapa hal yang mendasari rendahnya daya retensi siswa adalah tidak adanya keterkaitan antara rumus yang disajikan dengan masalah yang ada pada kehidupan sehari-hari. Rumus beserta aplikasinya hanya sekedar menjadi hapalan tanpa dapat diaplikasikan untuk menyelesaikan masalah yang nantinya akan siswa hadapi.

Salah satu materi pelajaran yang banyak menggunakan aplikasi atau penggunaan rumus adalah lingkaran. Pada materi lingkaran kita banyak dihadapkan pada rumus menghitu Luas lingkaran, Keliling Lingkaran, besar sudut pada tali busur lingkaran, besar sudut pada perpotongan dua tali busur lingkaran.

Untuk mengatasi masalah tersebut penulis ingin meningkatkan daya retensi siswa melalui Lesson Study dengan PBL (Problem Based Learning) pada materi lingkaran.

\section{Pembahasan}

Lesson study (LS) adalah kegiatan pengkajian berkelanjutan yang dilakukan sekelompok guru/dosen secara berkala dan berkelanjutan untuk menguji dan meningkatkan keefektifan pembelajaran [1]. Lesson Study adalah salah satu alternatif untuk mengembangkan profesionalisme pembelajaran untuk meningkatkan mutu pendidikan.

Lesson Study dilaksanakan dalam tiga tahap yaitu plan, do, see. Tahap plan (perencanaan) dilaksanakan dengan teman guru dengan mengutarakan masalah yang sedang di hadapi, diskusi pada tahap ini akan menghasilkan solusi berupa rencana pelaksanaan pembelajaran, focus dan target yang akan dilaksanakan. Tahap do (openclasss) adalah tahap observasi dan pengamatan dalam kelas dengan satu guru model dan beberapa pengamat, pada tahap ini pengamat dapat mengidentifikasi hal-hal penting yang terjadi di kelas. Tahap see (refleksi) adalah tahap mengutarakan apa yang terjadi selama proses pembelajaran dan mengambil pelajaran berharga dari pembelajaran yang telah berlangsung.

Melalui Lesson Study yang dilakukan diharapkan dapat mendorong siswa belajar dengan aktif, kreatif, tepat dan menyenangkan. Lesson Study juga dapat meningkatkan kemampuan observasi di kelas, meningkatkan kualitas pembelajaran yang akhirnya diharapkan melalui Lesson Study dapat memperbaiki kualitas pembelajaran di kelas.

Problem Based Learning (PBL) atau Pembelajaran Berbasis Masalah (PBM) didasarkan pada hasil penelitian Barrow dan Tamblyn [3] dan pertama kali diimplementasikan pada sekolah kedokteran di McMaster University Kanda pada tahun 60-an.

Barrow dan Tamblyn [3] mendefinisikan PBM sebagai

"The learning that results from the process of working towards the understanding of a resolution of a problem. The problem is encountered first in the learning process."

Sementara Chasman S. [5] mendefiniskan PBM sebagai

"...Problem-based learning (PBL) has been defined as a teaching strategy that "simultaneously develops problem-solving strategies, disciplinary knowledge, and skills by placing students in the active role as problemsolvers confronted with a structured problem which mirrors real-world problems".

Jadi, PBM atau PBL adalah suatu pendekatan pembelajaran yang mengguanakan maslah dunia nyata sebagai suatu konteks bagi peserta didik untuk belajar tentang cara berpikir kririt dan keterampilan pemecahan masalah, serta untuk memperoleh pengetahuan dan konsep yang esensial dari materi pelajaran. 
Landasan teori PBM adalah kolaborativisme, suatu pandangan yang berpendapat bahwa siswa akan menyusun pengetahuan degan cara membangun penalaran dari semua pengetahuan yang sudah dimlikinya dan dari semua yang diperoleh sebagai hasil kegiatan berinteraksi dengan sesama individu. Hal tersebut juga menyiratkan bahwa proses pembelajaran berpindah dati transfer informasi fasilitator siswa ke proses konstruksi pengetahuan yang sifatnya social dan individual. Menurut paham kosntruktivisme, manusia hanya dapat memahami melalui segala sesuatu yang dikonstruksinya sendiri.

Melalui pemahaman yang dapat dibangun sendiri oleh siswa melalui pembelajaran Berbasis Masalah diharapkan siswa dapat meningkatkan daya retensi siswa terhadap materi-materi yang ada pada pelajaran matematika.

Retensi adalah kemampuan untuk mengingat materi (seperti: konsep-konsep, teorema-teorema) yang telah dipelajari [4]. Retensi siswa yaitu kemampuan siswa untuk menyimpan hasil dari usaha untuk mendapatkan suatu kepandaian. Retensi siswa merupakan jumlah unjuk kerja yang masih mampu ditampilkan siswa setelah selang periode waktu tertentu dan mampu diungkapkan kembali oleh siswa [2]. Berdasarkan pengertian tersebut bahwa retensi siswa atau ingatan siswa adalah kemampuan yang ada pada diri siswa untuk menerima, memasukkan informasi, menimbulkan kembali hal-hal yang diperoleh sebelumnya.

Dari masalah yang ditemui, guru mata pelajaran berserta guru rumpun berdiskusi untuk mengatasi masalah tersebut. Dari diskusi yang dilakukan disepakati bahwa untuk pembelajaran materi lingkaran menggunakan pendekatan pembelajaran berbasis masalah (PBL). Melalui PBL diharapkan siswa memiliki daya retensi tinggi terhadap materi tersebut. Salah satu unjuk kerja yang dapat meningkatkan daya retensi adalah dengan menemukan prinsip [6]. Keefektifan belajar juga dapat diukur dengan tingkat retensi [6], sehingga pendekatan PBL pada penemuan rumus besar sudut perpotongan dua tali busur pada lingkaran ini diharapkan dapat meningatkan daya retensi siswa.

Kegiatan lesson study dalam mata pelajaran matematika dengan kompetensi dasar menentukan besar sudut pada perpotongan dua tali busur pada lingkaran dengan pendekatan PBL bertujuan agar tercapainya indikator pada rencana pelaksanaan pembelajaran (RPP) yang telah kita buat. Kegiatan Lesson Study yang dilakukan dapat membuat pembelajaran lebih aktif dan menyenangkan karena siswa dituntut untuk berfikir kritis dalam menyelesaikan lembar kegiatan yang telah diberikan. Lembar kegiatan yang diberikan mengarahkan siswa untuk dengan mudah menemukan rumus besar sudut pada perpotongan dua tali busur pada lingkaran.

\section{Metode \\ Plan}

Kegiatan lesson study diawali dengan plan yang dilaksanakan di SMPN 1 Baureno pada hari Senin, 08 Januari 2018 yang dihadiri oleh guru-guru matematika yaitu Ibu Endang Widowati, Ibu Eny Cahyo dan Bapak Alim. Pada saat plan disepakati Naning Kurniawati sebagai guru model yang akan menerapkan rancangan kegiatan pembelajaran sesuai plan. Pada tahap ini dilakukan pengkajian standar kompetensi dan kompetensi dasar, perumusan indikator dan tujuan pembelajaran, penetapan strategi pembelajaran, pemilihan media pembelajaran, penyusunan skenario pembelajaran dan penulisan RPP. Bahan ajar yang dipilih adalah standar kompetensi: menentukan besar sudut pada perpotongan dua tali busur. Kompetensi dasar: menentukan besar sudut pada tali busur lingkaran. Tujuan yang diharapkat pada saat pembelajaran, yaitu siswa dapat menemukan rumus dalam menentukan besar sudut yang terbentuk dari perpotongan dua tali busur baik di dalam lingkaran maupun diluar lingkaran.

Pada saat plan dihasilkan rencana pelaksanaan pembelajaran beserta lembar kegiatan peserta didik yang akan diterapkan pada tahap do (open class). Model pembelajaran yang dipilih adalah 
Cooperative Learning dengan pendekatan PBL. Pemilihan model pembelajaran kooperatif dengan PBL diharapkan dapat memberikan pengalaman belajar yang optimal.

\section{Do}

Tahap do dilaksanakan pada Selasa, 09 Januari 2018 di SMPN 1 Baureno. Pembelajaran Matematika materi besar sudut pada perpotongan dua tali busur pada lingkaran dilaksanakan di kelas VIII semester genap 2017/2018. Kegiatan do ini dihadiri oleh guru rumpun Matematika, perwakilan guru rumpun IPA dan kepala sekolah.

Pembelajaran pada tahap open class ini diawali dengan kegiatan menanyakan PR pada pertemuan sebelumnya. Karena tidak ada PR pada pertemuan sebelumnya siswa langsung diminta berkelompok sesuai kelompok yang telah ditetapkan. Masing-masing kelompok diberikan lembar kerja dengan materi besar sudut yang terbentuk dari perpotongan dua tali busur pada lingkaran.

Pada Kegiatan inti Masing-masing kelompok mendapatkan 2 Lembar kerja, satu untuk dikumpulkan dan satu untuk arsip kelompok. Pada lembar kerja terdapat 3 soal, setiap soal berisi permasalahan yang dapat menuntun siswa untuk menemukan rumus besar sudut yang terbentuk dari perpotongan dua tali busur pada lingkaran.

Masing-masing kelompok berdiskusi untuk menyelesaikan permasalahan pada soal 1 . Pada soal 1 hampir tidak ada pertanyaan karena berisi cara menentukan besar sudut pada tali busur lingkaran, yang pada dasarnya materi ini telah disampaikan pada pertemuan sebelumnya.

Pada soal 2 terdapat 2 pertanyaan. Pertanyaan pertama berisi permasalahan yang memuat gambar perpotongan dua tali busur di dalam lingakaran dan Pertanyaan kedua berisi permasalahan yang memuat gambar perpotongan dua tali busur di luar lingkaran siswa agak bingung karena tali busur yang da pada lingkaran saling berpotongan di dalam lingkaran. Beberapa kelompok melontarkan kebingungan mereka, kelompok 5 berpendapat bahwa gambar yang disajikan salah, sehingga perlu diralat. Kelompok 2 tampak lebih serius 38 berdiskusi di pimpin oleh siswa yang bernama Zeni. Pada soal 2 ini diberikan beberapa besar sudut yang diketahui sebagai petunjuk dalam menentukan besar sudut perpotongan dua tali busur. Beberapa kelompok yang merasa kebingungan diberikan petunjuk oleh guru model. Beberapa kelompok sudah dapat memecahkan masalah yang dihadapi, hanya kelompok 6 yang masih sulit memahami permasalah yang diberikan. Tetapi guru model terus memberikan pembimbingan sehingga seluruh kelompok dapat memecahkan masalah pada soal 2.

Setelah soal 2 selesai, masing-masing kelompok berdiskusi tentang soal 3 yang mengarahkan siswa langkah demi langkah untuk menyusun rumus menentukan besar sudut pada tali busur lingkaran. Sebagian siswa merasa kesulitan karena tidak membaca permasalahan pada pertanyaan dengan baik. Kemudian guru memberikan pengarahan agar siswa memahami pertanyaan terlebih dahulu sebelum menjawab. Kelompok 2 tampak tidak menemui kesulitan apapun. Kelompok lain dapat mengerjakan setelah mendapat arahan dari guru.. Pada dasarnya mereka sudah bisa menjawab tetapi tidak yakin akan jawaban mereka karena memang hanya dalam bentuk variabel. Jawaban dari pertanyaan 6 merupakan rumus menentukan besar sudut pada tali busur lingkaran.

Setelah masing-masing kelompok menyelesaikan lembar kerja kemudian di kumpulkan, siswa diminta untuk kembali ke meja masing-masing untuk mengikuti evaluasi. Pada kegiatan akhir masing-masing siswa mengerjakan soal individu sebagai penilaian. Siswa terlihat antusias dalam mengerjakan, hanya Aditya tampak santai dalam menjawab dan Noviani banyak tengak tengok. Angga dan Jessica tampak bingung dalam menjawab dan dalam waktu lama mereka belum bisa menulis jawaban apapun.

\section{See}

Kegiatan See (Merefleksi) dilaksanakan langsung setelah open class. Kegiatan refleksi dipimpin oleh moderator. Sebagai moderator 
adalah Bapak Alim. Moderator mengingatkan kepada observer bahwa obyek observasi adalah peserta didik dan aktivitasnya selama proses pembelajaran. Kegiatan refleksi bukan kegiatan menghakimi guru. Kegiatan refleksi diharapkan adanya temuan masalah, penyebabnya, dan pemberian solusi, sehingga dapat diketahui pelajaran berharga yang dapat dipetik dari pembelajaran tersebut.

Kegiatan refleksi dimulai oleh moderator dengan memberi ucapan selamat pada guru model yang bersedia mengimplementasikan perangkat pembelajaran yang telah disusun bersama. Selanjutnya moderator memberi kesempatan kepada guru model untuk menyampaikan pengalaman mengajarnya, melakukan refleksi apakah pembelajaran sudah dilaksanakan sesuai dengan RPP yang dibuat pada saat plan? Guru model menjelaskan perasaannya waktu mengajar, ketercapaian keterlaksanaan pembelajaran, kesesuaian langkah pembelajaran dengan RPP yang dipersiapkan dan hasil pengamatan selama proses pembelajaran. Pada kegiatan $d o$, penulis (guru model) belum melakukan beberapa langkah pembelajaran (seperti pada RPP), antara lain belum dapat memberikan kesempatan kepada siswa untuk melakukan presentasi di depan kelas dan belum dapat melakukan penilaian unjuk kerja secara individu pada masingmasing siswa. Hal ini dikarenakan waktu yang sangat singkat.

Selanjutnya penyampaian hasil observasi dari semua observer tentang kegiatan belajar peserta didik, diantaranya sebagai berikut.

- Bagaimana kesiapan belajar peserta didik? (respon ketika guru mempersiapkan belajar peserta didik)

- Bagaimana interaksi yang terjadi dalam pembelajaran : peserta didik dengan peserta didik dan peserta didik dengan guru? (kapan dimulai dan sampai kapan terjadi).

- Mengapa peserta didik tidak belajar/konsentrasi?

- Bagaimana jalan keluar mengatasi peserta didik yang tidak belajar?
- Bagaimana peserta didik terlibat dalam kegiatan penutup (melakukan refleksi, merangkum, dan sebagainya)?

- Pelajaran apa yang dapat dipetik dari kejadian tersebut?

Kritik dan saran disampaikan secara bijak tanpa merendahkan guru (80\% memuji, 20\% memberikan masukan/saran dan kritikan yang bersifat positif)

\section{Hasil dan Diskusi \\ Hasil Observasi}

Hasil observasi berikut didasarkan pada lembar pengamatan lesson study.

\section{Kegiatan Pendahuluan}

\section{Kesiapan siswa pada awal pembelajaran}

Siswa pada awal pembelajaran siap dan antusias. Siswa terlihat antusias untuk membentuk kelompok sesuai dengan perintah guru. Siswa juga terlihat sangat bersemangat untuk mengkuti pembelajaran pada pertemuan ini.

Kondisi/respon siswa ketika guru menyampaikan kegiatan apersepsi/ motivasi/ pemanasan berpikir/advance organizer

Siswa merespon dengan cepat. Terlihat Zeni langsung membuka buku paket sesuai dengan materi yang akan dipelajari. Terlihat juga pada saat pembagian kelompok, setiap siswa langsung bergerak cepat menuju kelompoknya masing-masing.

\section{Kegiatan Inti}

Interaksi yang terjadi dalam pembelajaran dan gangguan dalam belajar

Peserta didik saling berinteraksi baik ketika mulai diskusi tentang permasalahan yang diberikan hingga akhir diskusi. Interaksi siswa dengan guru juga baik, siswa yang belum mengerti langsung bertanya pada guru dan guru segera merespon pertanyaan siswa.

Beberapa siswa yang tidak dapat mengikuti pelajaran adalah Jessica (pasif), Ridho (Mengantuk), Nabila (Cerita), Indra (bersandar), Nia (tidak fokus). Kelompok 1 terlihat ramai karena beda pendapat. Beberapa siswa juga terlihat dapat memberikan ide dalam 
pemecahan masalah diantaranya Zeni, Marisa dan Bima.

Penyebab siswa tidak dapat belajar dengan baik dan Usaha guru untuk mengatasi gangguan belajar dan Alternatif yang dapat dilakukan untuk mengatasi siswa yang terganggu dalam belajar

Jessica dan Ridho terlihat mengalami kesulitan dalam mengikuti pembelajaran. Kesulitan yang dialami dikarenakan sulitnya memahami masalah yang diberikan. Untuk mengatasi hal ini guru harus lebih aktif dalam memberikan pembimbingan kepada siswa baik kelompok demi kelompok maupun dari individu ke individu. Kelompok yang bermasalah dapat diberikan arahan lebih dengan pertanyaan umpan. Siswa yang belum memahami permasalahan diberikan kondisi yang berbeda dengan topik yang sama. Guru memberikan lebih banyak motivasi, dorongan dan memberikan Lembar Kerja pada masingmasing siswa.

Usaha guru dalam mendorong peserta didik yang tidak aktif belajar

Pada saat pembelajaran guru berkeliling ke setiap kelompok dan menanyakan kesulitan atau masalah yang sedang dihadapi, memberikan pertanyaan serta memberikan penjelasan kepada masing-masing kelompok. Tetapi penjelasan guru tidak bisa langsung diserap oleh semua anggota kelompok, hanya 12 orang yang dapat memahami penjelasan dari guru, sehingga guru meminta siswa yang telah memahami untuk menjelaskan kepada anggota kelompok yang lain atau tutor sebaya.

\section{Kegiatan Penutup}

Siswa yang terlibat dalam kegiatan penutup

Siswa tampak bersemangat dalam mengikuti kegiatan inti yaitu penilaian individu. Tetapi banyak siswa yang bingung dengan soal no 3 karena marumuskan dengan bentuk variabel, untuk mengatasi masalah tersebut guru menjelaskan maksud dari soal no.3. Akhirnya siswa memahami maksud no.3 dan dapat megerjakan. Beberapa siswa juga tampak bingung karena lupa dengan rumus yang telah ditemukan tadi karena siswa tersebut kurang aktif dalam mengikuti diskusi kelompok. Terbukti bahwa siswa yang kurang mengikuti diskusi mendapatkan hasil penilaian individu yanng kurang bagus.

\section{Hikmah Pembelajaran}

Pelajaran berharga apa yang dapat Anda petik dari pengamatan pembelajaran hari ini?

Pelajaran berharga yang dapat diambil adalah melalui diskusi siswa dapat berfikir kritis sehingga dapat menyelesaikan masalah dan menurunkan rumus dengan baik dan benar. Dari diskusi kelompok siswa dapat sharing atau tukar pendapat dengan anggota kelompok lain dan bertanggung jawab atas dirinya sendiri dan kelompok. Diskusi kelompok serta bimbingan dari guru sangat penting untuk pengetahuan yang bersifat prinsip dan prosedural.

\section{Penutup}

Kegiatan pembelajaran Matematika yang dilaksanakan pada open class di kelas VIII SMPN 1 Baureno dengan materi menentukan besar sudut pada perpotongan dua tali busur pada lingkaran ternyata mampu mengarahkan siswa untuk dapat menemukan rumus sehingga dapat meningkatkan daya retensi siswa dalam merumuskan prinsip dan mengaplikasi rumus tersebut dan dapat membuat siswa berfikir kritis dalam menyelesaikan masalah

\section{Referensi}

[1] Syamsuri, I dan Ibrohim. Lesson Study: Studi Pembelajaran. Malang : UM Press (2011).

[2] Degeng, I Nyoman Sudana. Ilmu Pengajaran Taksonomi Variabel. Jakarta (1989).

[3] Barrows and Tamblyn. Problem Based Learning An Approach to Medical Education. New York : Springer Publishing Company (1980).

[4] Yusuf, Muhammad. Teori Pembelajaran: Retensi, artikel (2011). Diambil dari http://yusufsila.blogspot.com/2011/10/teori -pembelajaran-retensi.html, pada tanggal 15 Nopember 2017. 
[5] Chasman S. An Overview of problem Based Learning. (2003). diambil dari https://depts. washington.edu/ccph/pdf_files/handout4.p df, pada tanggal 16 Nopember 2017.
[6] Elviana. Teori Belajar Gagne. (2014). Diambil dari https://elviana09.wordpress. com/2014/09/30/teori-gagne/, pada tanggal 20 Nopember 2017. 
